within; even the fins, the anal one in particular, being indicated by projections of the surface, so that the external form of the concretion is plainly due to the contained fossil. On the other hand, a broad very flat concretion, with an irregularly rounded circumference, contained some vertebræ and other bones of the same Fish.

4. Yoldia (Leda) pygmaa ; in one case associated with an Annelid, in another with a Fish.

5. Ophiura Sarsii; one specimen in a thin flat concretion, slightly convex on both sides, and which, though very hard, seemed less calcareous than usual, and was internally of a lighter colour and contained much mica. The circumference was prolonged into five flat points of different sizes, but corresponding to the arms, and presenting some of the spines and plates, from the form of which the species is determined. Judging by the thickness of the arms, this specimen must have been as large as or larger than those found living by Dr. Sars in Finmark; and had fully attained the size of the living Greenland form, which, according to Lütken, has a body $27 \mathrm{~mm} .=1 \cdot 1$ inch in diameter. Here, as in the case of the Fishes, the form of the concretion was obviously determined by the shape of its contents ; and here, therefore, we have a further illustration of the singular manner in which, during the process of decomposition, the particles of carbonate or lime contained in the clay were drawn together by the influence of the organic body, and concentrated around it in a hardened mass.

Among other facts of interest which Dr. Sars mentions in connection with the Glacial formation is the distinct diminution southwards of the Arctic character of the strictly Arctic Shells present in the clays. As they extend further south they fall off both in frequency and in size. Thus the Siphonodentalium vitreum is found living in Finmark and fossil as far south as Christiania ; and the living specimens from the north and those fossil from the south of Norway agree very closely in size, being from $\frac{2}{5}$ to $\frac{1}{2}$ inch (10 to $12 \mathrm{~mm}$.) long, by $\frac{1}{10}$ inch $\left(2 \frac{1}{2} \mathrm{~mm}\right.$.) broad at the base, whereas the fossil specimens from further north, in the neighbourhood of Trondhjem, are $\frac{4}{5}$ inch $\left(20 \mathrm{~mm}\right.$.) long, and $\frac{1}{7}$ inch $\left(3 \frac{3}{4} \mathrm{~mm}\right.$.) broad, and some seem to have attained even 1 or $1 \cdot 1$ inch in length, and $\frac{1}{5}$ inch in breadth.

On the other hand, it is a very curious fact that some shells extended further north in the Glacial epoch than they do now; thus Scrobicularia piperala, which has never in a living state been found further north than Florö in the Bergenstift, appears in the Glacial Clay at Surendal and at Trondhjem. Pecten maximus, too, which is unknown living further north than Christiansund, is found in the clay at Steenkjwr, at the very head of the Trondhjem Fjord, and sixty miles north of that town.

Saggto sulla Costtuduone Geologrca della Protincta dr Pisa; del Prof. Cav. PaOLI Savi. 1863. 4to. Pisa. pp. 42.

THIS account of the Geology of the neighbourhood of Pisa by its veteran Professor is accompanied by an elaborate general map, with excellent sections, and special maps of the neighbourhood of

VOL. I.-NO. IV. 
Volterra, near which ancient town are the celebrated copper-mines of Monte Catini and the soffioni boraciferi, or hot vapours containing minerals, now conveyed into pools of water and yielding large supplies of the borate of soda (the borax of commerce). Few parts of Italy are more interesting to the geologist, and he could not find a guide more intelligent, lively, or trustworthy than M. Savi.

Almost the whole province lies to the south of the Arno, and it includes about seventy miles of coast, the width of the belt varying from ten to twenty miles. The Arno and the Cecina cross it at right angles; the coast is generally low, and often marshy, and there are ranges of hill parallel to the coast a few miles distant. Some idea of the geological interest of the district may be obtained from the statement, that it presents marked varieties of Palæozoic rocks, together with Liassic, Jurassic, Upper and Lower Cretaceous, Upper and Lower Eocene, very varied Miocene, Pliocene, and Post-pliocene deposits. Some of these are broken through by serpentines, trachytes, and porphyries, or are penetrated by modern volcanic vapours. The whole district is subject to earthquakes.

The result of a very superficial glance at the orographical structure of Tuscany shows-(1) that it presents three varieties of surfacemountains, hills, and plains ; (2) that the mountains form geologically three chains-the Apennines, the metalliferous chain, and the serpentine chain; (3) that the hills are also of three kinds-Miocene, Pliocene, and Recent. All of these but the Apennines exist in the province of Pisa. The Palæozoic rocks are chiefly of the Carboniferous period, and of the kind known locally as verrucano, consisting of clayslate, talcschist, \&c., and they are well marked by occasional fossils, both vegetable and animal. They are limited to the northernmost part of the province, where it adjoins the territory of Lucca, and the mountains enclosing the celebrated Baths of Lucca. Rocks apparently Triassic are present in small quantity between the verrucano and the River Serchio, and on both banks of the Serchio. They are covered with Liassic and Jurassic rocks to a limited extent. These recur on the flanks of Monte Calvi, at the southern extremity of the province, where they are brought up by trachytic and porphyritic rocks. Elsewhere they are covered by newer deposits. The Cretaceous rocks are also exhibited on Monte Calvi ; the alberese overlying the Jurassic rocks on the southern side. Other examples were seen on the flanks of the serpentines near Monte Catini, and they doubtless extend below the Miocene and Pliocene rocks to the north. They occur again to the east of Volterra in similar position, but the whole amount exhibited at the surface is small, and the rocks are almost entirely Upper Cretaceous.

Eocene rocks, both Nummulitic Limestones and the rock called macigno, are much more extensively developed, and occupy large tracts in the districts south of the Cecina. It is chiefly the upper member that is seen. This rock also is called alberese; but it is quite distinct from the Cretaceous alberese. It is pierced through by the trachytes of Monte Calvi, and also by numerous smaller eruptions of serpentine. These are seen in three groups-one near 
the Soffioni, where borax is worked; another at and near Monte Catini, where copper exists in abundance ; and a third on the coast to the east of the Monte Catini group. As it is through the Eocene deposits that the serpentines chiefly appear, so the Miocene beds, which cover them towards the east, are interpenetrated by the boraciferous vapours, and contain gypsum and salt. The Miocenes are, for the most part, recomposed rocks, derived from the serpentines and macigno. They are often highly bituminous. The Pliocene rocks occur between the alluvial valleys of the Arno and the Cecina, and the Miocene and Eocene rocks to the south and east. They cover a large space, probably a third of the whole area of the province. They are chiefly sand and clay, and they are loaded with fossil shells. The newer rocks are the alluvial clays and sands of the Arno and the coast.

The chain of serpentine hills, commencing a little to the south of Leghorn, with the littoral group from Montenero to Rosignano, continues towards the south-east, coming to the surface at intervals, and always of the same general nature. The rocks are essentially metamorphic, consisting of altered Upper Cretaceous and Eocene aqueous deposits, the limit betweeu the two having been determined in 1850 by Sir R. Murchison. This demarcation, says Prof. Savi, is the more important in Italian geology ' because the last Secondary and the first Tertiary rocks were deposited in conformable stratification at the bottom of the same sea, of which the fauna and flora changed gradually, not abruptly, insomuch that no precise line can be drawn between the two,' p. 15. It is well known that the Nummulitic Limestone forms this horizon; but, while it is unquestionable that the pietra-forte, immediately underlying the Nummulitic Limestone, and loaded with Upper Chalk fossils, is Secondary, and that everything above the Nummulitic Limestone is Tertiary, it is yet impossible to draw a precise limitary line between Upper Chalk and Lower Eocene, for the bands of schistose clay, limestone, and finegrained sandstone among the Nummulitic Limestone are perfectly conformable both above and below, and present a mixture of fossils of the two epochs. The Eocene deposits form two distinct series.

Penetratiug and altering these beds are erupted rocks, of probably two periods, both converting them into serpentines. The older is a dark-green ophiolite, with much diallage, generally confined to the Lower Focenes, but also reaching:the Upper. Large veins of euphotide belong to this eruption, and they have altered very extensively the Upper Cretaceous and Lower Eocene rocks, chiefly producing from them a rock known as gabbro rosso, abounding with zeolitic minerals, and often putting on all the characters of a plutonic rock. Argentiferous lead, copper, and zinc occur in the veins in this rock. Other veins penetrate the rocks metamorphosed by this first eruption. They are certainly more modern, and they affect the Miocene deposits. They present a peculiar rock, not containing diallage, but abounding with sulphurets of copper, lead, iron, and zinc, which have been accumulated in some veins in great quantities. Several minerals and veins are described by $\mathbf{M}$. Savi as affecting these rocks. 
The Miocene chain is interesting on three accounts : it contains (1) lignite, (2) rock-salt, and (3) alabaster. Each of these is econonomically important; but the reader must refer to the original memoir for a detailed notice of them. The Pliocene hills are also interesting, but they are less important.

Belonging to the later Tertiary periods are numerous volcanic rocks covering the Pliocene rocks. The extinct volcanos range from north to south, and connect the existing volcanos of South Italy and Sicily with the recent movements and modifications of the rocks in Tuscany. The greater part of these phenomena seem to runge parallel with the metalliferous chain and that of the serpentine hills._-D. T. A.

Der Kulm in Thüringen. Von Herrn R. Richter, in Saalfeld. (Zeitsch. deutsch. geol. Gesell., vol. xvi. Heft 1, pp. 155-172. 1864.)

TTWO areas of ' Culm' (or Lower Carboniferous strata) occur on 1 the slate of the Thuringian Forest. The northern Culm strata come from under thin beds of Roth-and Weiss-liegende, which are covered by the Zechstein (Magnesian Limestone); their boundary reaching from Saalfeld to Weida; the floor of the Culm consists of Upper and Middle Devonian rocks. The southern area reaches to the neighbourhood of Stockheim, where there are productive coalmeasures; and the Culm here also reposes on Devonian rocks.

These Lower Carboniferous strata occur on the ridges of the hills, dipping away on both sides, the strike varying from NE.-SW. to E. by S.-W. by N. The beds are much disturbed. The total thickness is not clearly indicated, but is small. The rocks are throughout similar, the Culm-formation consisting chiefly of sandstone with shale-partings. There is also a conglomerate sparingly distributed. The conglomerate consists of rounded fragments of glassy and common quartz, of minerals resembling decomposed felspar, of mica, and fragments of schist. It is an irregular deposit; and the organic remains in it are rare and indeterminable. The sandstone, in beds several feet thick, is more regular. It is separated by shaly beds, loaded with fossils in good condition. Shales occur throughout the whole deposit, but they are rarely more than a few inches thick. These are composed sometimes almost exclusively of regetable remains. The author believes that the Lehesten roofing-slates are not, as supposed by Gümbel ('Bavaria,' III.), of the Lower Carboniferous age. They seem distinctly Devonian, by the character of the vegetable remains as well as by position. Plutonic rocks are not known within the Culm-district.

The fossils found are for the most part fragmentary and in bad condition. They are as follow (figured in five plates) :-

I. Proetus posthumus, sp. n.; Cythere spinosa, sp.n. ; Litorina, sp.; Cardiomorpha (?) tellinaria (?), Goldf.; Crinoidea ; several fragments, one resembling Lophocrinus speciosus, Meyer.

II. Plants-Pinites Catharine, sp. n.; a small seed, not unlike that of Abies alba, Mill., but larger. Several fragments of fossil 
coniferous wood probably belong to this species; Megaphytum (Rothenbergia) Hollebeni, Cotta ; Sagenaria transversa, Göppert ; S. Veltheimiana. Presl; S. remota, Göppert; S. (?) cyclostigma, Göppert ; S. minutissima, Göppert ; Lycopodites, sp. ; Odontopteris Stichleriana, Göppert; Calamites transitionis, Göppert (in great variety of markings) ; Fucoides bipinnatus, sp. n. There are also two fossils figured, whose nature is doubtful ; one of them allied apparently to Harlania.

The above fauna is exclusicely marine; and one, at least, of the plants has had the same habitat; the rest of the plants, however, cannot have grown under water. We have thus indications of a sea not very far from land; Encrinites, belonging to deep water, being drifted up occasionally. A deposit of sand stretches up towards the north-east, from the present Thuringian Forest, as far as the outcrop can be traced; and there is a parallel formation of limestone at some distance. 'Thus the 'Culm' of Thuringia may be the equivalent of the Carboniferous Limestone.

'The stratification of the Thuringian Culm is only here and thero conformable, and it is faulted differently in different members; so that it appears that it is distinct in this respect both from the underlying Devonian and overlying Permian rocks.

The Culm-sandstone is available for walls and occasionally for paving, while thin slabs are useful for oven-plates. Neither the coal nor the iron would be good for speculation. The decomıposed rock makes a tolerably good soil. - D. T. A.

Dir Fauna der Braunkohlenformation von Latdorf bei Bernberg. Von C. Gieber. pp. 93. 4 plates. (From the Abhandlungen der Naturforschenden Gesellschaft zu Halle. Vol. viii. 1864.)

A LTHOUGH perhaps the only memoir which has hitherto been A specially devoted to a description of the strata of Latdorf is that by Herr C. Zincken in the ' Zeitschrift für gesammten Naturwissenschaften,' * the fossils from this locality have furnished material, wholly or in part, for several papers. Thus the Bryozoa were first described by Dr. Ferd. Stoliczka, $\dagger$ and afterwards, with the Corals, by Dr. F. A. Roemer, $\ddagger$ which memoir has since been rather severely criticized by Dr. Stoliczka, in a letter to the Editors of the 'Neues Jahrbuch,' $\oint$ these two palæontologists differing very materially in their views of the limits of specific variation, and on other points. Some of the Shells have been described by Dr. Semper in the 'Archiv der Meklenburger Freunde der Naturgeschichte,' $\|$ and others in Prof. Beyrich's work on the North-German Tertiary Shells, besides which most books and pamphlets on German Oligocene strata or fossils contain more or less direct references to those of this very celebrated locality.

* Vol. xxi. 1863 , p. 530 , pl. 3.

† Sitzungsberichte der k. k. Wiener Akad, vol, xlv. pp. 71-79.

$\ddagger$ Palæontographica, vol. ix. Heft 1 .

il Vol. xv. 1861, pp. 221-409. 
The anthor of the present paper has from time to time published descriptions of new species from the Brown-coal of Latdorf in the 'Zeitsch. gesammt. Naturw.,' and in this memoir he reproduces these descriptions, adding others of new species, with notes on some old ones, giving figures of the forms now described for the first time, and of those which, though described by him before in the ' Zeitschrift,' had not yet been figured. He also gives lists of all the species of Shells, Bryozoa, and Corals that have been described from this locality, or have been noticed as occurring there.

Among the new species we notice one under the name of Thecided oblonga, and, although the figure is so bad that it shews nothing besides the general form of the shell, that alone is sufficient to suggest the probability of its being the same species as that referred to by Mr. Davidson* as Thecidium Mediterraneum, var. Latdorfiense. Dr. Giebel considers it, however, a new species, but his description contains scarcely any allusion to the internal arrangements, he himself considering that 'the form and the condition of the surface are quite sufficient to distinguish this species from all others.' The surface is described as wrinkled and punctate (wurmfrassig), and exhibiting the lines of growth only towards the margin; the shell is said to be oblong in shape, strongly vaulted, and becoming only a little narrower towards the beak, which is very thick; the hingeline is straight. Dr. Giebel also states that it is the only species found in the Tertiary beds of Germany.-H. M. J.

Sopra I Dfpositi dr Piante Fossint dell' America Setwtentrionale, delle Inde, e dell' AUStralia che alclini Autori rifgrirono all' Epoca OoliTICA; Memoria del Cav. A. de Zigno. (From the Proceed. Acad. Sciences of Padua. 8vo. 1863.)

TN every group of natural objects, or natural phenomena, which 1 has been the subject of classification, there must be certain members having such mixed characters that it is difficult to say to which of the two or more neighbouring groups they more properly belong. Geology furnishes many such instances, some of more than usual difficulty, and especially the case of the age of certain plantbearing strata, occurring in several distant regions, and having all a greater or less community of character, as exhibited in the facies of the fossils they contain.

The Baron de Zigno, who has before written on the subject, has recently published in the paper before us a résumé of the facts and opinions current respecting the age of these several plant-bearing strata, which have been referred by some to the Oolitic Period. From the title it will be seen that the deposits in question occur in North America, India, and Australia; but strata containing similar fossils to those occurring in India and Australia occur also in South Africa, though Sign. de Zigno does not mention them.

The chief conclusions of Sign. de Zigno, and the facts adduced in support of them, may be thus stated. The flora of Rajmahal

* Geological Magazine, No. 1, p. 18, Pl. I., figs. 6-9. 
(Bengal) he considers to have, on the whole, a Liassic facies, although

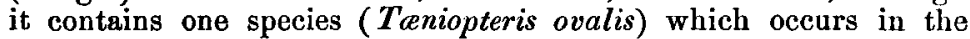
Oolitic strata of Scarborough, and another, which he cannot distinguish from the Dictyopteris Brongniarti of the Carboniferous (!) rocks of Saxony. Some of the species of Cycads are allied to those found in the Oolite, others to Liassic species, and some to species occurring in Triassic rocks; but the Liassic forms are said to be most prevalent. Respecting the North American beds, the author evidently inclines to the opinion that they are Triassic; he denies the correctness of Prof. Rogers's determinations of the plants, but accepts those of Dr. Heer ; the former geologist endeavoured to show that these North American deposits were comparable with the Oolitic coal-bearing beds of Whitby, while the latter referred them either to the Keuper or the Lower Lias. The Australian strata are more difficult to deal with, for while Professor $\mathbf{M}^{\prime}$ Coy considers the plants to be Oolitic, the Rev. W. B. Clarke asserts that he has found associated with them a true Carboniferous Lepidodendron, with Shells belonging to the same period. Sign. de Zigno coincides and Prof. M'Coy in believing that the Lepidodendron and the Palæozoic shells found by the Rev. W. B. Clarke came from deposits much lower in the series than the strata which furnished the remaining plants; but he differs from the Australian Professor as to the age of the latter, believing them to be either Trias or Lias. Thus it will be seen that Sign. de Zigno considers all these deposits as referable either to the Trias or the Lias. This conclusion is not new, and, excluding the Australian beds, the age of which cannot as yet be considered determined, it is probably right, although the author's arguments, derived from the very conflicting evidence of the Plants, are by no means so convincing as those of Professor Rupert Jones, which are drawn from the occurrence, in the Indian and American strata, of certain species of Estheria, a genus, by the way, which Sign. de Zigno does not even mention, referring to the Richmond specimens of E. ovata as shells allied to 'Posidonomya' minuta. Not less remarkable in the Memoir is the absence of all allusion to the remarkable Glossopteris Browniana, which is said to occur in India, Australia, and South Africa; for even if Sign. de Zigno prefers another generic name, the specific appellation ought still to remain; but these omissions, with the absence of allusion to the South African deposits, convince us that the author has not jet got to the bottom of this very intricate subject.-H. M. J.

Uhberblick Über diz Trias, mT Berücksichtigung inRes Vorkommens IN DEN Alipen. Von Dr. Friedrich von Alberti. Stuttgart, 1864. 8vo. pp. 353. 7 Plates.

THE object of this work is to give an outline of the present state 1 of our knowledge of the Trias, and thus to complete or to correct the remarks made by the author in his memoir entitled 'Beitrag zu einer Monographie des bunten Sandsteins, Muschelkalks und Keupers, und die Verbindung dieser Gebilde zu einer Formation (Trias), 
which was published in 1834, and in which the name 'Trias' was first given to this formation.

The author divides his subject into three portions, to each of which he assigns a special chapter. In the first chapter he treats of the various groups composing the Swabian Trias, coupled with remarks on the mineralogical components and contents of the rocks, chiefly from a geological point of view. In the second part of the work he describes the org :nic remains of the Triassic strata, including some new species of Mollusca, giving figures of the latter, and of some of the former that have not been adequately illustrated before. In the third chapter he discusses the distribution and range of the fossils in the Trias of Swabia and other countries, and combats some of the published classifications of this group for the Alps and other districts.

The following is the classification he adopts :-

SwabIa, \&c.

Atrs.

C. Keuper.

cc. Upper Kerper.

p. Täbingen Beds . . . . Kössen Beds.

Lower Dachstein.

Bleiberg Beds.

o. Coarse-grained Sandstone.

n. Gansingen Beds.

$m$. Fine-grained Sandstone.

l. Keuper-gypsum. $\quad$ Esino Beds.

bb. Middle Keuper.

Arlberg Limestone.

Hallstadt Limestone.

k. Cannstatt Beds . . . . St. Cassian Beds.

Wengen Beds.

Partnach Beds.

Mendola Dolomite.

i. Upper Dolomite.

aa. Lower Keuper or Lettenkohlengruppe.

$h$. Lettenkohle and Sandstone.

g. Gypsum and Rocksalt.

f. Lower Dolomite.

B. Muschelkalk.

e. Friedrichshall Limestone . $\cdot\left\{\begin{array}{l}\text { Virgloria Limestone. } \\ \text { Guttenstein Limestone. } \\ \text { Recoaro Limestone. }\end{array}\right.$

d. Anhydrite Group . . . Gypsum of the Muschelkalk of Lombardy.

c. Wellenkalk . . . $\quad\left\{\begin{array}{l}\text { Campiler Beds. } \\ \text { Seiss Beds. }\end{array}\right.$

A. Bunter.

b. Upper Bunter Sandstone.

a. Vosges Sandstone. \} Grödner Sandstone. .

The author states that in the Trias there are four principal 
Coprolite-beds ('Cloake'), besides others of less importance, namely: 1. Below the Lettenkohlensandstein. 2. Between the horizon of Beaumont and the Keuper-gypsum. 3. In the Keuper-sandstone (o). 4. In the Kössen beds (Täbingen) immediately below the Lias.

These deposits (Cloake), he observes, have all the same character; they form great layers in the beds in which they occur, and contain teeth, bodies, and scales of various Fishes and Reptiles, mixed and cemented together with Coprolites.-H. M. J.

Leoneard und Geinitz's Neugs Jahrbuch für Mrneralogte, Geologie, und PaL

RESIDES the usual notices of Mineralogical, Geological, and Palæontological memoirs, the last number of the 'Jahrbuch' contains the following papers:-

1. Vorläufiger Bericht über krystallinische Silikatgesteine des Fassathales und benachbarter Gegenden Südtyrols, von Herrn T. Scheerer. (Preliminary notice on the Crystalline Siliceous rocks of the Fassathal and neighbouring districts of South Tyrol.)

In this paper the author divides the different rocks occurring in the district under consideration into two great classes, namely, the Hochsilicirte Gesteine (or Plutonites) and the Niedrigsilicirte Gesteine (or Vulcanites). These classes are again subdivided, so that all the rocks of the Fassa Valley are arranged as follows:-

I. Highly silicated rocks (Plutonites).

Average per-centage

1. Upper Plutonite, or Red Gneiss . . . 75

Gneiss.

Quartz-porphyry (remelted gneiss).

2. Middle Plutonite, or Middle Gneiss . • . . 70

Granite of Brixen.

Granite of the Cima d'Asta.

3. Lower Plutonite, or Grey Gneiss . . . . 65

Tourmaline-granite.

Quartz-porphyry.

II. Subsilicated rocks (Vulcanites).

$A$. Plutovulcanite.

1. Upper Plutovulcanite, or Quartziferous Syenite $\quad 63$ Quartz-syenite.

2. Middle Plutovulcanite, or ordinary Syenite . . 60 Monzon Syenite.

Syenite-porphyry.

Nicaceous Syenite.

3. Lower Plutovulcanite, or Melaphyr . . . . 55

$B$. Vulcanite. Melaphyr.

1. Upper Vulcanite, or Augite-porphyry 48 Augite-porphyry.

Uralite-porphyry.

Monzon Hypersthenite.

2. Middle Vulcanite, or ordinary Basalt . . 42 Basalt.

3. Lower Vulcanite, or basic Basalt . . . 36 Basic Basalt. 
2. Auszug aus der Denkschrift des Herrn Alphons Milne-Edwards über die geologische Vertheilung der fossilen Vögel. Zusammengefasst von Herrn A. Fr. Grafen Marschall. An abstract of this paper has been already given in the Geological Magazine, No. 2.

3. Chemische Untersuchung einiger Gesteine von Java. Von Herrn Otto Prölss. This contains analyses and descriptions of some volcanic rocks from Java, by a young Heidelberg doctor, a pupil of Blum and Bunsen.

4. Der Erloschene Vulkan Ringgit in Ost-Java und sein angeblicher Ausbruch 1586. Von Herrn Emil Stöhr. (The Extinct Volcano Ringgit, in Eastern Java, and its pretended Eruption in 1586.) In this paper the author attempts to prove that the eruption of this extinct volcano, asserted by Houtman to have occurred in 1586 , and to have caused the death of 10,000 people, did not really take place; but that an eruption of the Raun Mountain, which is still active, occurred in that year, and was mistaken by Houtman for an eruption of the Ringgit.

In a letter, Dr. J. A. Roemer gives a sketch of a new classification of the Sponges, which he is about to use in his forthcoming Monograph of the North-German Cretaceous Sponges, to be published in the 'Palæontographica,' illustrated by 18 plates. 'The numbers after the genera indicate the number of species.

1. Family Coeloptychidea.

1. Coeloptychium, 6 .

2. Camerospongia, 7.

3. Cephalites, 8.

4. Cystispongia, 7 .

5. Porospongia, 2.

6. Lepidospongia, 1.

2. Family Cribospongidea.

7. Cribospongia, 17.

8. Coscinopora, 3.

9. Pleurostoma, 7.

10. Retispongia, 4.

11. Oscillaria, 12.

12. Ventriculites, 10.

13. Dendrospongia, 3.

14. Cylindrospongia, 11.

15. Diplostoma, 6.

\section{Family Siphonidea.}

\section{A. Eudeidea.}

16. Hippalimus, 2.

17. Placospongia, 4 .

18. Eudea, 3.

19. Siphonia, 5.

B. Siphonocclidea.

20. Siphonocolia, 14.

21. Polycolia, 10 .

22. Elasmoccelia, 2.
23. Jeren, 18

C. Jereidea.

24. Polyierea, 6 .

25. Marginospongia, 1.

26. Limnorea, 4.

4. Family Limnoreidea.

27. Eperdea, 1.

28. Epithebes, 4.

29. Polenydostoma, 3 .

30. Endostoma, 2.

31. Tremospongia, 4.

32. Actinospongia, 2.

33. Enaulofungia, 3.

34. Lecospongia, 3.

5. Family Chenendoporidea.

35. Chenendopora, 12.

36. Verrucospongia, 4.

37. Elasmostoma, 5.

6. Family Sparsispongidea.

38. Monothebes, 2.

39. Disthebes, 4.

40. Oculispongia, 4.

41. Stellispongia, 10.

7. Family Amorphospongidea.

42. Copulospongia, 13.

43. Mæandrospongia, 4.

44. Thalamospongia, 1.

45. Amorphospongia, 12

H. M. J. 